\title{
Hydrodynamics and Recharge of the Aioune Sandstone Aquifer in the Taoudenni Transboundary Basin in Mauritania
}

\author{
Bacar Sidi Haiba Teiss ${ }^{1,2}$, Serigne Faye ${ }^{1}$ \\ ${ }^{1}$ Department of Geology, Cheikh Anta Diop University, Dakar, Senegal \\ ${ }^{2}$ National Water Resources Center, Nouakchott, Mauritania \\ Email: bacar_teis@yahoo.fr
}

How to cite this paper: Teiss, B.S.H. and Faye, S. (2018) Hydrodynamics and Recharge of the Aioune Sandstone Aquifer in the Taoudenni Transboundary Basin in Mauritania. Journal of Water Resource and Protection, 10, 681-698.

https://doi.org/10.4236/jwarp.2018.107039

Received: April 29, 2018

Accepted: July 14, 2018

Published: July 17, 2018

Copyright ( $) 2018$ by authors and Scientific Research Publishing Inc. This work is licensed under the Creative Commons Attribution International License (CC BY 4.0).

http://creativecommons.org/licenses/by/4.0/

\begin{abstract}
In Mauritanian, 4/5 of the territory is subject to an arid climate, where groundwater resources are the main sources of drinking water for populations and livestock. The study area is located in south-eastern Mauritania and in the western part of the Taoudenni Transboundary Basin. A better knowledge of the hydrogeological system to ensure a sustainable and rational management is necessary for this vulnerable water resource. This pioneering study, based on the compilation of hydrogeological, geochemical and isotopic data, aims to characterize the hydrodynamics and recharge of this one layer aquifer system, composed of Aioune infracambrian sandstone. The piezometric surface exhibits relatively the same morphology of the soil topography, and computed effective velocity is $94 \mathrm{~m} / \mathrm{yr}$ (Northeast area), and the direction of flow is generally from cliff to plains area. The chemical data show water types evolving between two poles namely the $\mathrm{HCO}_{3}-\mathrm{Ca} / \mathrm{Mg}$ pole (low mineralized), and the $\mathrm{Cl}-\mathrm{Ca} / \mathrm{Na}$ pole; these waters are characterized by a high vulnerability to pollution, especially at shallow depth area (Douerare, Aioune). The dissolution of bicarbonate and evaporate minerals is likely the main source of mineralization. The isotopic tool used to support comprehension of the system functioning, evidences a local indirect recharge water localized at the cliff or Wadi zones. The age of the waters ranges from the present to 1060 year. The recharge rate calculated by ${ }^{14} \mathrm{C}$ and the chloride masse balance is respectively 0.4 to $5 \mathrm{~mm}$ /year. This recharge compared to the water pumping rate is lower and hence this imbalance is likely the cause of water shortages particularly during summer season period.
\end{abstract}

\section{Keywords}

Aioune, Isotopes, Hydrochemistry, Piezometry, Recharge 


\section{Introduction}

In Mauritania, $4 / 5$ of the territory is subject to an arid climate, where groundwater resources are the main sources of drinking water supply for populations and livestock.

The study area is located in southeast Mauritania, and covers the southern part of the Taoudenni Basin in Mauritania. It is characterized by a high concentration of livestock (49\%) [1], and a high spatio-temporal variability in rainfall and increasing population pressure on water resources, which cause water shortages and decrease in boreholes yield.

The implementation of sustainable water resources management plan is essential in this context which requires a better knowledge of the system functioning. The present work aims to investigate the hydrodynamic and hydrochemical characteristics of Aioune sandstone aquifer, the most important generalized aquifer in the Taoudenni transboundary basin in Mauritania, and to identify and quantify the recharge at this Aioune sandstone aquifer. Hydrodynamic, hydrochemical and isotopic data used in this study are powerful tools to identify the origin, the age of the water, mineralization processes as well as location of recharge areas in order to establish measures for sustainability of these valuable water resources [2].

\section{Study Area Description}

\subsection{Geography}

The study area called "Afolle" is located in the southern part of the Taoudenni Transboundary Basin in Mauritania. It has a triangular shape and covers an area of $21,000 \mathrm{~km}^{2}$. In the center of the basin, culminates a cliff of $350 \mathrm{~m}$ IGN which is strongly affected by weathering and its borders are covered in the North, East and West by recent sedimentary layers (Figure 1).

\subsection{Climate}

The climate in the study area is generally Sahelian. Rainfall is irregular, and occurs mainly between July and October, with an average of $200 \mathrm{~mm}$ at Aioune station (Figure 2(a)). 70\% of annual rainfall events have an intensity between 10 - $30 \mathrm{~mm}$ [3]. The series of rainfall data (1939-2006) is characterized by a deficit cycle (1969-1990), followed by slightly increase relative to annual mean (Figure $2(\mathrm{~b})$ ). The average temperature is $30^{\circ} \mathrm{C}$, with peaks of heat in May and June. Mean annual PICHE evaporation at Aioune zone is $5.32 \mathrm{~m}$ [4].

\subsection{Hydrography}

Apart the Senegal River, there is no perennial flow in Mauritania. In the study area, the hydrographic network is more active in the center, with a coefficient of flow between $1.5 \%-10 \%$ [4].

The tributaries of the Senegal River in the study area are mainly the "Kolimbine" Wadi to the east of Afolle, and to the West the Wadi "Karakoro". These 
Wadis are currently cut by sandy cover (endoreism), which is often present in the study area [4] (Figure 3).

\subsection{Geology and Hydrogeological Context}

Several French geologists, studied this zone, from the 19th century to the 1960s (H. HUBERT, R. HUDEAU, R. FURON and C. BENSE) and had identified an anticlinal structure inferred by tectonics, with the North, East and West edges plunging under recent sedimentation layers (Figure 1). The Afolle relief is characterized by a succession of tabular formations affected by numerous diaclases. The oldest sedimentary formations which outcrop are the sandstones of the

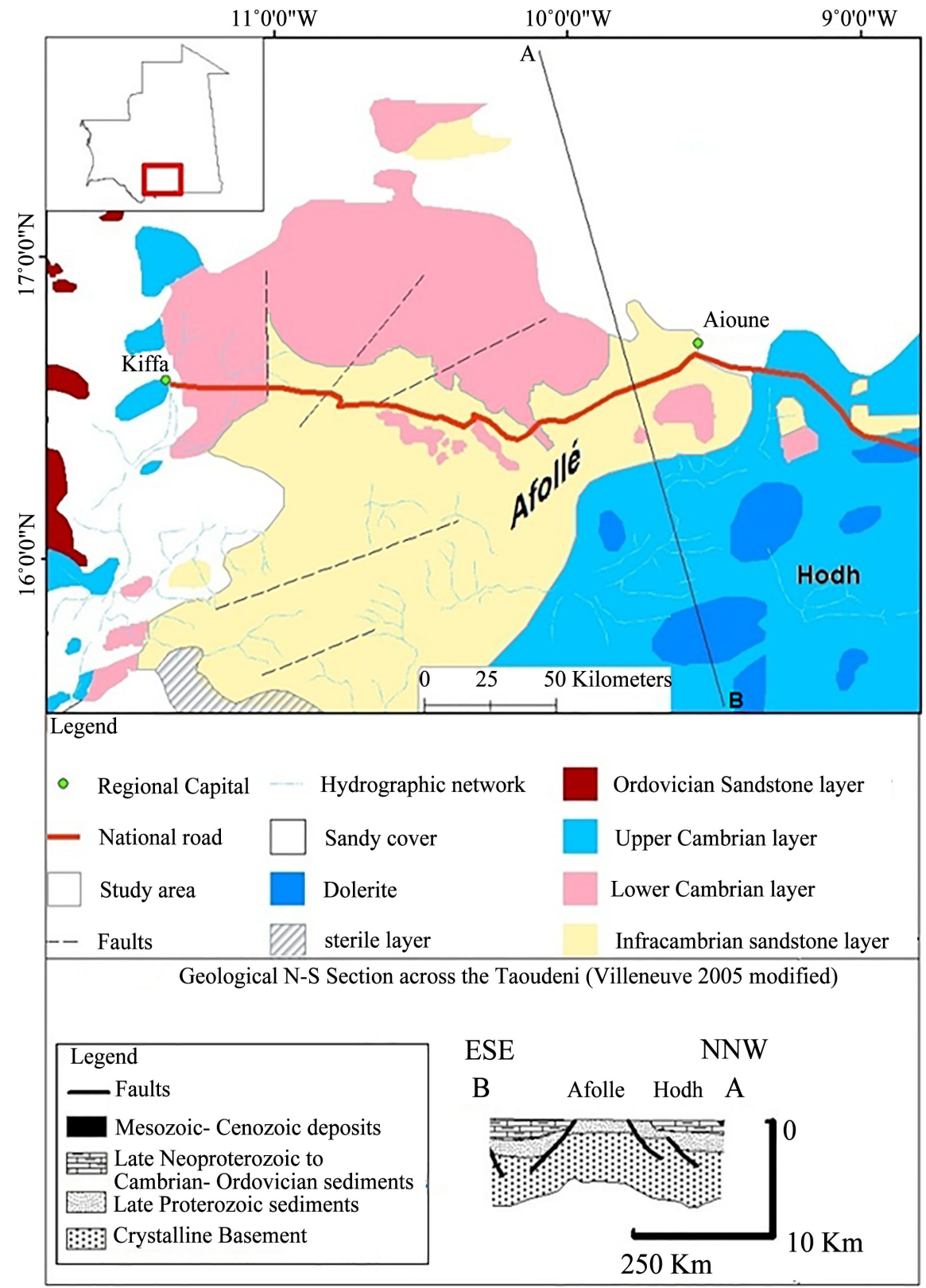

Figure 1. Geology, section cross $\mathrm{AB}$ and localization map of the Aioune aquifer area. 


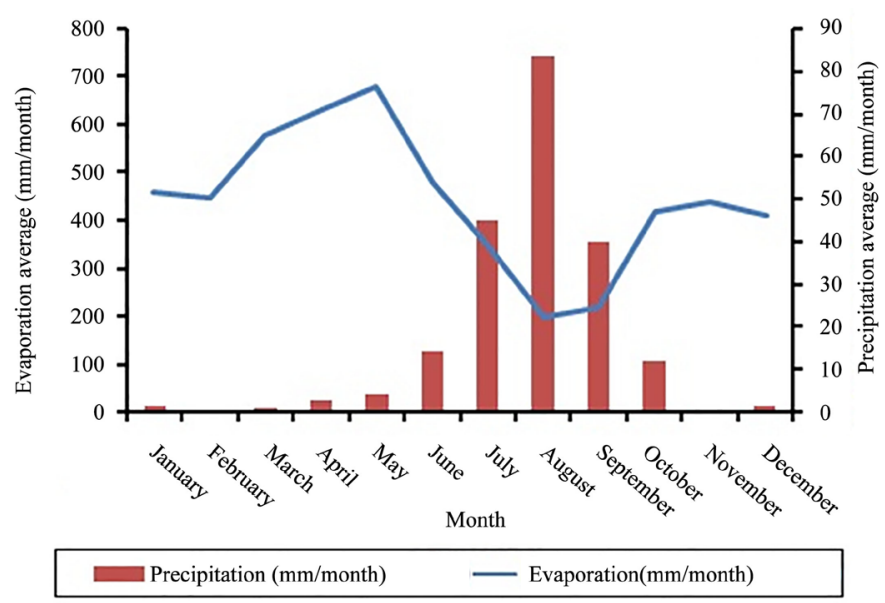

(a)

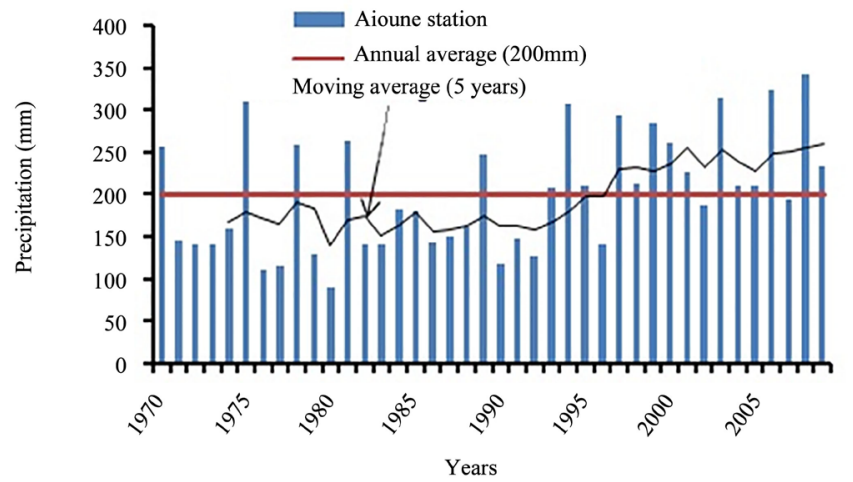

(b)

Figure 2. (a) Pluviometric and evaporation average per month at aioune station (1970-2009); (b) Pluviometric variation average per year to the Aioune station (1970-2009).

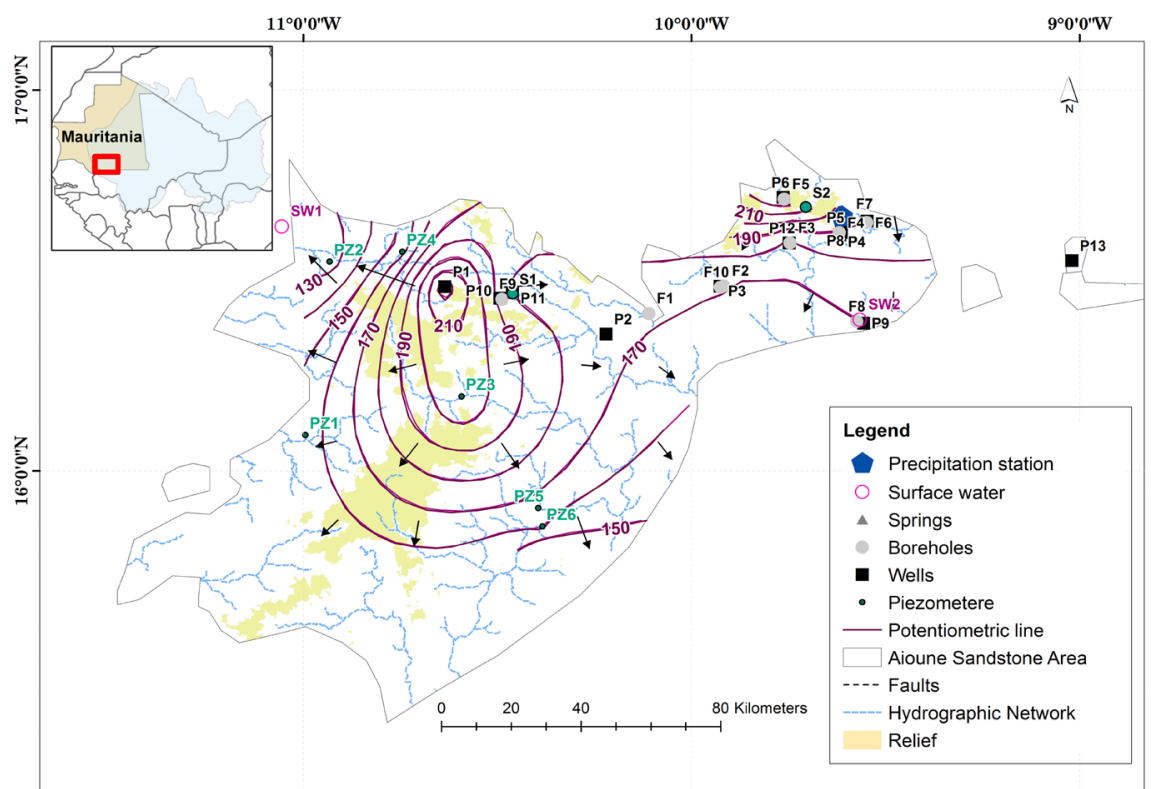

Figure 3. Piezometric head map of aioune groundwater (Auguste 2013). 
infracambrian series. This sedimentary series unconformably overlay the granitic basement of "Birrimien". The infracambrian series begin at the base with basic compact clayey quartzite sandstones of $400-1000 \mathrm{~m}$ thickness [5], covered by ferruginous sandstones which extents a large area and have oblique stratification, called "Aioune sandstones". This unit is between 80 and $120 \mathrm{~m}$ in thickness, and its oblique stratification characteristic could be due to strong marine currents during the past [6]. At the top, the infracambrian series occur with the sandstone compact quartzite "brain sandstone". The thickness of the infracambrian series is in the order of $2000 \mathrm{~m} \mathrm{[7].}$

In the north, the previous series are covered in angular unconformity [7], by the lower Cambrian outcrop series, which begin at the base with coarse sandstones, interspersed by a granite cobble clay conglomerate of so-called glacial origin, namely Tillite. The thickness of this series in the west is $210 \mathrm{~m}$ [5]. To the West and East, the upper Cambrian outcrop is characterized by the presence of the Pelite, jasper and dolomitic limestone minerals.

The study area is characterized by a large extension of the unconsolidated and interstratified sandstone of Aioune [7]. This formation becomes aquifer in area where are favorable conditions occur [4], such as the primary and secondary permeabilities of the Aioune sandstone formation occur. The superficial part of this formation mostly exhibits these characteristics. The thickness of the one layer aquifer of "Grès d'Aioune" is variable, with an average of $15 \mathrm{~m}$ [8]. The static level varies between 2 and $35 \mathrm{~m}$ below ground surface. The average transmissivity is $6 \times$ $10^{-4} \mathrm{~m}^{2} / \mathrm{s}$. The porosity in the order of $5 \%$ and flow rates can reach $15 \mathrm{~m}^{3} / \mathrm{h}[8]$, and the renewable reserve is estimated at 2.1 million $\mathrm{m}^{3} /$ year [7].

\section{Methodology}

A total of 23 groundwater samples, two springs water samples, and two surface water samples, were collected from the Aioune sandstone aquifer, in December 2011 and September 2013. In addition rainwater samples covering only the rainy events of August 2013 were collected during the couese of this stady. Physico-chemical parameters ( $\mathrm{pH}$, conductivity, temperature) were measured on site. The determination of the concentration of the major elements (28 samples) was carried out by high performance liquid chromatography (HPLC). The stable isotopes were analyzed by the laser spectrometer (28 samples). The tritium content was performed by liquid scintillator after electrolytic enrichment (28 samples). Only ten samples were analyzed for ${ }^{14} \mathrm{C}$ and ${ }^{13} \mathrm{C}$. The radiocarbon analyses were performed by accelerator mass spectrometry (AMS). All analyses were carried out at the Laboratory of Radio-Analyzes and Environment (LRAE) of ENIS of Sfax (Tunisia) except for ${ }^{14} \mathrm{C}$ and ${ }^{13} \mathrm{C}$, carried out at the isotopic laboratory of the University of Groningen (Holland). The analytical errors on the measurements are $\pm 0.2 \%$ o for oxygen- $18, \pm 0.6 \%$ o for deuterium, for Tritium $\pm 0.3 \%$ ond carbon-13 (Table 1).

Only the chemical balance data of $\pm 5 \%$ were considered. 


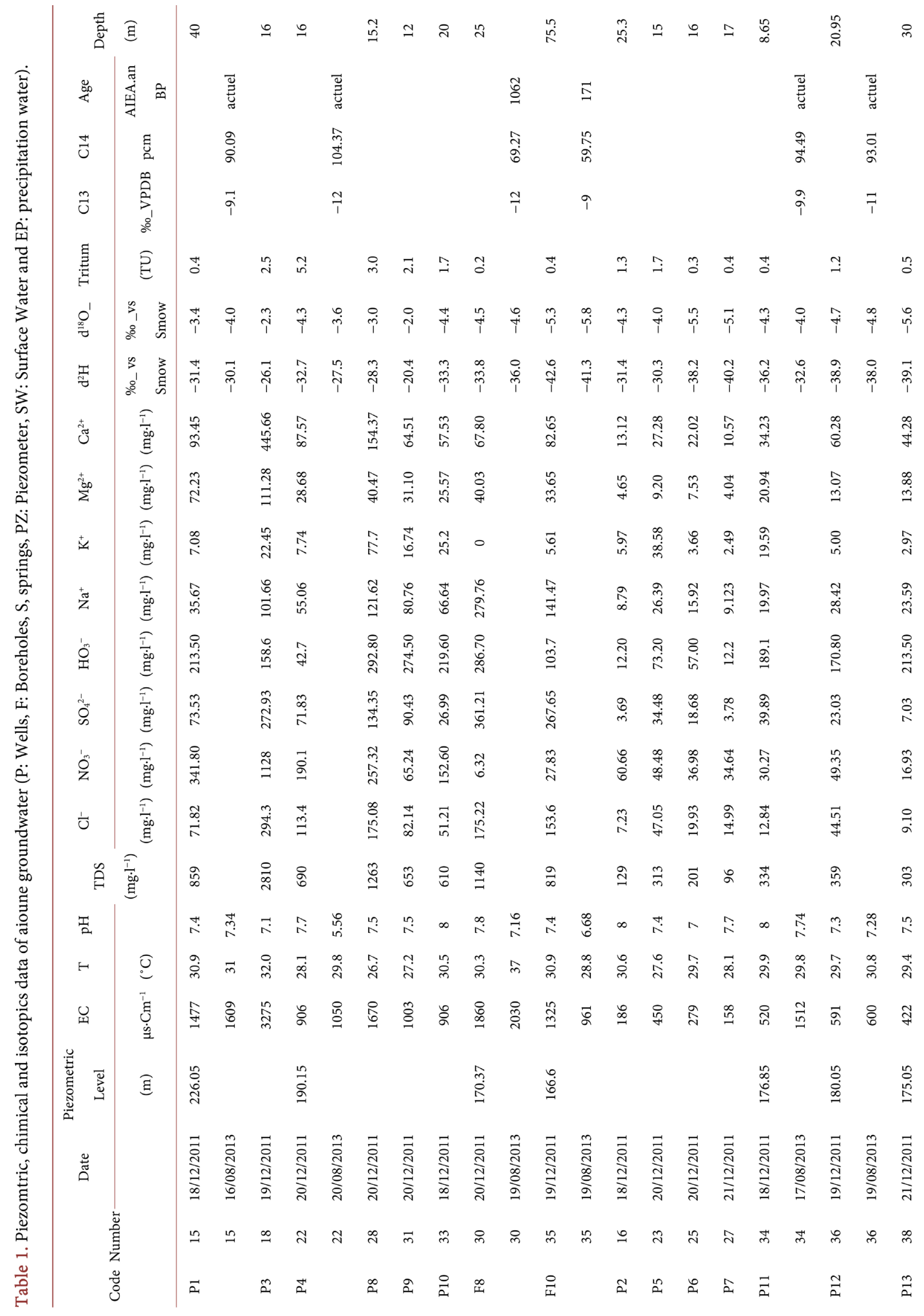




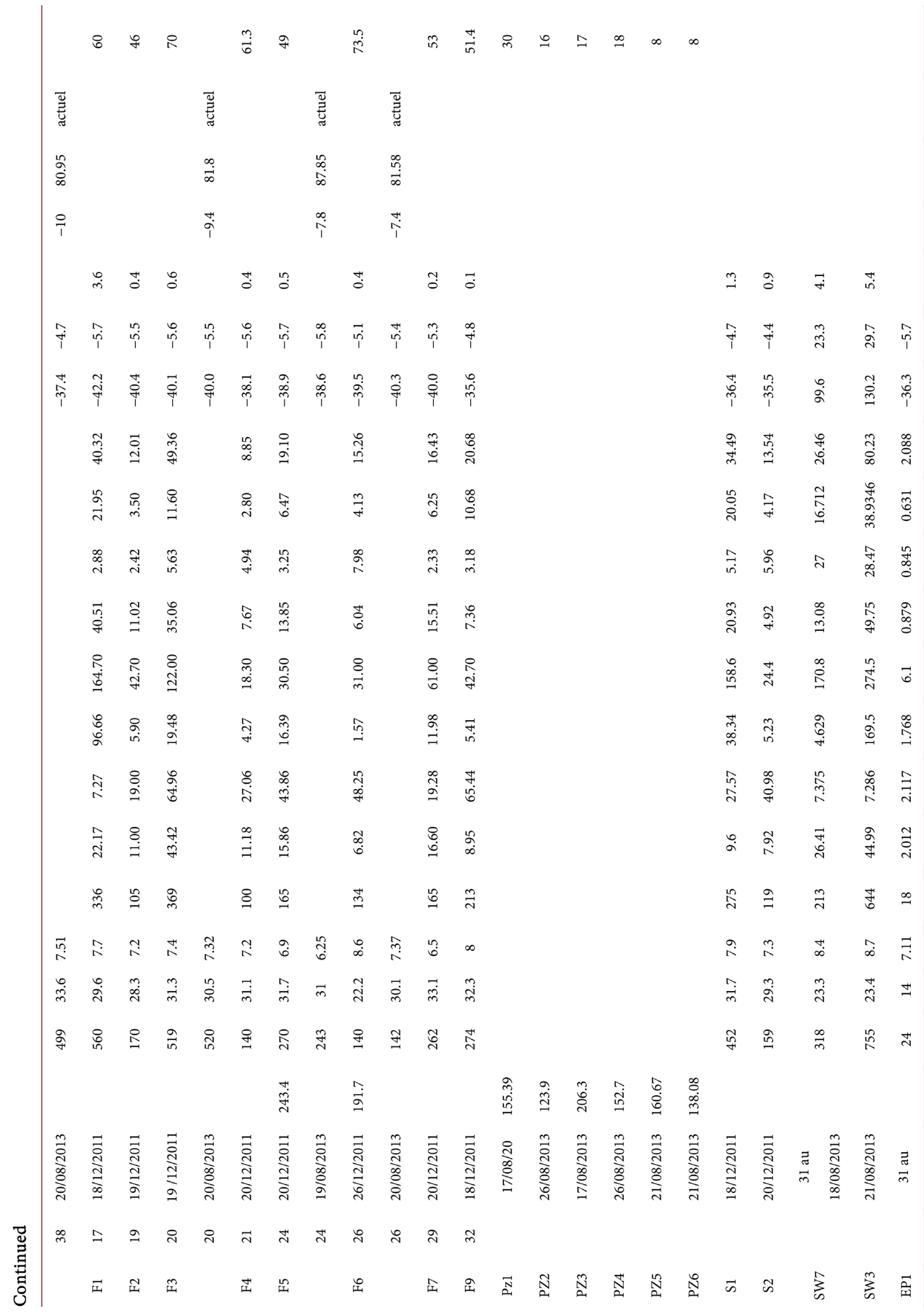


The rainfall samples collected at the Aioune station are representative $\left(\left(\left({ }^{2} \mathrm{H}-\left({ }^{18} \mathrm{O}{ }^{\star} 8\right)\right)-10\right): 0.7\right)$, located on the global meteorological water line, and are in the range of stable isotope values recorded at the nearby GNIP station (Bamako (Mali) and Niamey (Niger) (Table 2).

The correct Bamako GNIP data (low deviation from mean $\left(\left({ }^{2} \mathrm{H}-\left({ }^{18} \mathrm{O}{ }^{\star} 8\right)-10\right)\right)$, and extrapolated from the Vienna GNIP series, were used in tritium tracing.

\section{Results and Discussions}

\subsection{Piezometry}

Head data measured from 16 piezometers were used to establish piezometric map of Aioune groundwater. The piezometric surface morphology of the aquifer follows the soil topography, characterizing a low depth water table (water table). Head values range between 238 and $143 \mathrm{~m}$ of altitude and the flow direction is generally from the cliff towards the plains (Figure 4). The hydraulic gradient calculated for this water table varies between 1 and 5\%o, the effective velocity is $94 \mathrm{~m} /$ year (Figure 3).

The data collected in 2013, at the National Hydraulic Database (SIPPE2) [9], were additionally used and extrapolated to evaluate the volume taken in 2006, which is estimated at $18,000 \mathrm{~m}^{3} / \mathrm{d}$ (represents 6.5 million $\mathrm{m}^{3} /$ year).

\subsection{Hydrochemical Characteristics}

\subsubsection{Surface Water and Rainfall}

In December 2011 and August 2013, two samples of surface water were collected from the study area, and all the August 2011 rain events greater than $5 \mathrm{~mm}$, at the Aioune station. The average temperatures are $23^{\circ} \mathrm{C}$ and $14^{\circ} \mathrm{C}$, respectively for surface water and rainwater. The average $\mathrm{pH}$ is 8.2 and 7.1, respectively for surface water and rain. Salinity ranges from 318 to $755 \mathrm{mg} / \mathrm{l}$ for surface water and $18 \mathrm{mg} / \mathrm{l}$ for rainwater. The surface water and rain samples exhibit $\mathrm{HCO}_{3}-\mathrm{Ca}$ water type.

\subsubsection{Groundwater}

\section{1) Salinity and chemical facies}

The chemical and physicochemical data from the 2011 campaign samples were assessed to evaluate the chemical quality of the water in the study area and identify the geochemical processes controlling mineralization of the groundwater.

Indeed, depending on the sampling points, the waters were classified into three groups: wells, boreholes and springs (Figure 1).

The temperatures range from $33.1^{\circ} \mathrm{C}$ (Borehole F7) to $27.2^{\circ} \mathrm{C}(\mathrm{P} 8$ Well), with average $30^{\circ} \mathrm{C}$, and show some increase in depth, except for El Ghouds borehole (F6).

The $\mathrm{pH}$ varies between 6.5 and 8.6, with an average of 7.5. The electric 
Table 2. Stable isotopes of precipitation in the study area and near regional stations sample name.

\begin{tabular}{cccccccccccccc}
\hline & $\begin{array}{c}\delta^{2} \mathrm{H}(\% \text { vs } \\
\text { Smow) }\end{array}$ & ${ }^{2} \mathrm{H}_{-}$ERR & $\begin{array}{c}\delta^{18} \mathrm{O}(\% \mathrm{o} \\
\text { vs Smow })\end{array}$ & ${ }^{18} \mathrm{O} \_$ERR & Date & Latitude & Longitude & Altitude & Type & Prof & Locality \\
\hline EP1 & -36.3 & 0.9 & -5.7 & 0.1 & $\begin{array}{c}31 \mathrm{au} \\
18 / 08 / 2013\end{array}$ & 16.6102 & -7.281 & 230 & Rainfall & 0 & Aioune \\
Bamako & -45.40 & & -6.58 & - & & 12.6932 & -7.995 & 381 & Rainfall & 0 & Bamako \\
Niamey & -40.10 & & -5.78 & - & & 13.5200 & 2.090 & 220 & Rain & 0 & Niamey \\
\hline
\end{tabular}
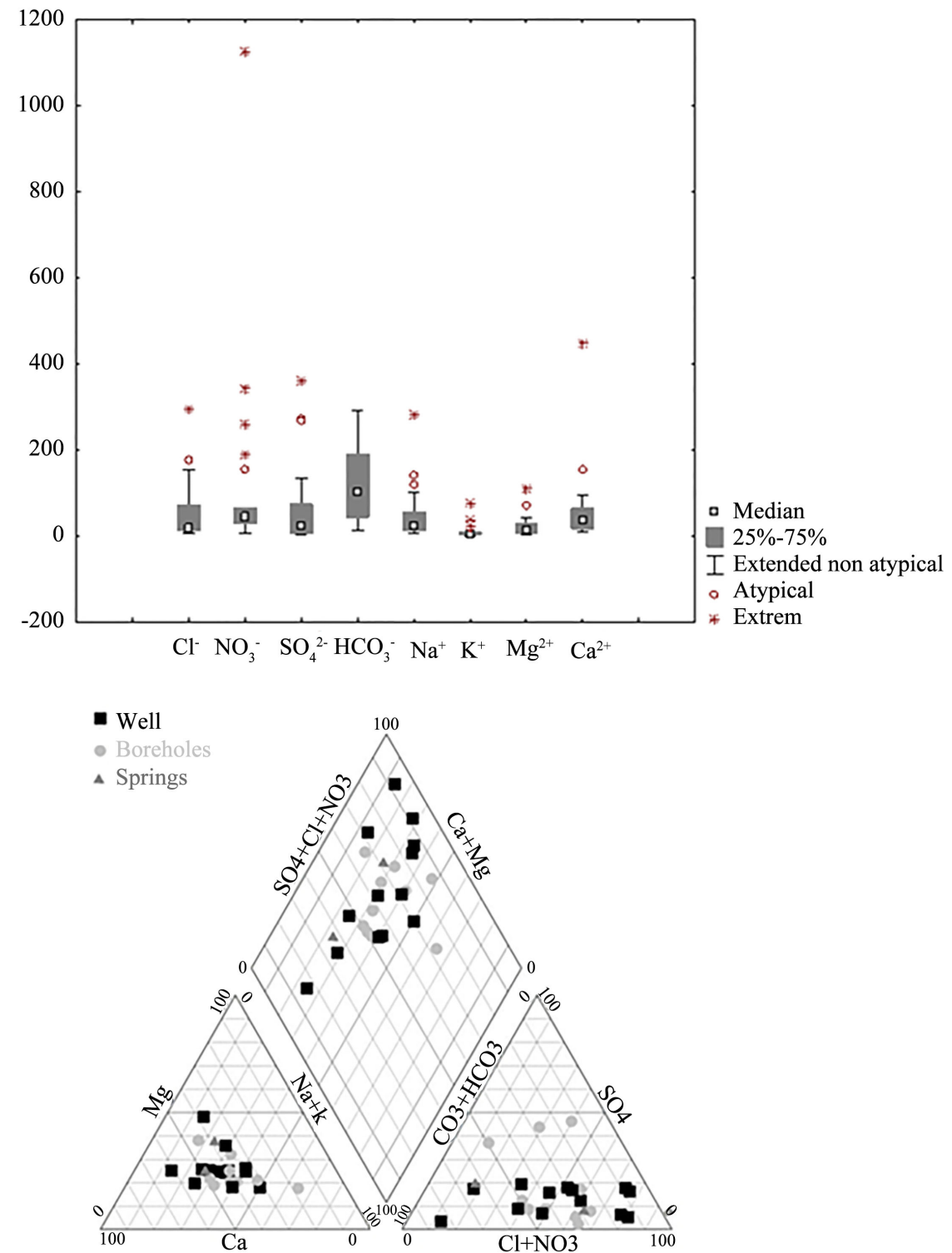

Figure 4. (a) Major elements of the Aioune sandstone water; (b) Piper diagram of the analysed Aioune groundwater samples.

conductivity varies from $140 \mu \mathrm{s} / \mathrm{cm}$ to $3200 \mu \mathrm{s} / \mathrm{cm}$, and the average is $451 \mu \mathrm{s} / \mathrm{cm}$. The spatial distribution of the electric conductivity shows higher values in the shallow depth of the alluvial spreading zones and in particular near the major 
agglomerations (eg Gounguel, Aioune, etc.).

The general order of abundance of the cations in meq is $\mathrm{Ca}^{2+}>\mathrm{Na}^{+}>\mathrm{Mg}^{2+}>$ $\mathrm{K}^{+}$, with the exception of few water points where $\mathrm{Na}>\mathrm{Ca}$. For anions, the general order is $\mathrm{HCO}_{3}^{-}>\mathrm{NO}_{3}^{-}>\mathrm{Cl}^{-}>\mathrm{SO}_{4}^{2-}$, with high concentrations of Nitrates, reaching $1.1 \mathrm{~g} / \mathrm{l}$, mainly in the shallow level, reflects the vulnerability of the water table to the pollution (Figure 4(a)).

The representation of the chemical data in the Piper diagram shows waters whose chemical facies evolve mainly between two poles, a $\mathrm{HCO}_{3}$ - $\mathrm{Ca}$ (low mineralized) pole, and a $\mathrm{Cl}-\mathrm{Ca} / \mathrm{Na}$ (generally more mineralized) pole. Some other facies types occur such as, $\mathrm{HCO}_{3}-\mathrm{Ca} / \mathrm{Na}, \mathrm{HCO}_{3}-\mathrm{Na} / \mathrm{Ca}, \mathrm{HCO}_{3}-\mathrm{Na}$ and $\mathrm{SO}_{4}-\mathrm{Na}$, reflecting concommittent other chemical processes (Figure 4(b)).

\section{2) Geochemical processes}

In order to determine the origin of the mineralization of the Aioune sandstone groundwaters samples, some correlations between the main major elements have been studied, notably with $\mathrm{Cl}$ which is considered as conservative.

The positive correlation between $\mathrm{Ca} / \mathrm{Cl}$ vs. $\mathrm{Cl}$ (Figure 5(a)) generally indicates the contribution of this element to mineralization, and similarly for $\mathrm{Na} / \mathrm{Cl}$ vs. $\mathrm{Cl}$ (Figure 5(c)), indicates the significance of the contribution of these elements. These elements generally result from the dissolution of carbonates and evaporites and the basic exchange phenomenon. The $\mathrm{K}$ and $\mathrm{Mg}$ elements do not show a clear trend (Figure 5(b) and Figure 5(d)).

The positive correlation between $\mathrm{Ca}, \mathrm{Mg}, \mathrm{HCO}_{3}$ and $\mathrm{SO}_{4}$ (Figures $5(\mathrm{e})$ and Figures 5(f)), probably reflects carbonates and gypsum dissolution phenomenon. Figure $5(\mathrm{~g})$ shows a good correlation between $\mathrm{Na}, \mathrm{K}$ and $\mathrm{HCO}_{3}$, up to high values $\left(3\right.$ meq-1-1 $\left.{ }^{-1}\right)$ of $\mathrm{HCO}_{3}$, where there is a stability of the $\mathrm{HCO}_{3}$ concentration, the increase in $\mathrm{Na}+\mathrm{K}$, can be explained by the achievement of the equilibrium of water with respect to the carbonates, therefore the presence of the phenomenon of precipitation-dissolution.

Figure 5(h) indicates the presence of both types of cationic exchange with type I clays through the release in water of $\mathrm{Ca}^{2+}$ and or $\mathrm{Mg}^{2+}$ ions against fixation $\mathrm{Na}^{+}$ion (P 3), and type II, where the $\mathrm{Na}^{+}$ions of the complex are released and are replaced by the $\mathrm{Ca}^{2+}$ (F8) ions [2]. This cationic exchange mainly affects the mineralized waters, which are close to the alluvial spreading (Gounguel Zone, Douerare etc.).

Saturation index (SI) vs. major elements (Figure 6) show waters mostly saturated to supersaturated in carbonates, which explain by the presence of the phenomena of precipitation/dissolution of carbonates (Figures 6(a)-(c)). The waters are generally under-saturated in evaporite, which explains by the presence of the phenomenon of dissolution of evaporites (Figures 6(d)-(f)) [10].

The high exposure of the aquifer to contamination is probably due to variation in the unsaturated zone thickness $(<30 \mathrm{~m})$, characterizing a water shallow. 


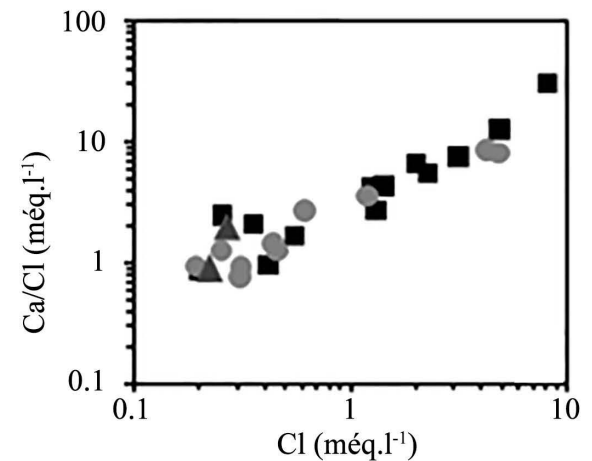

(a)

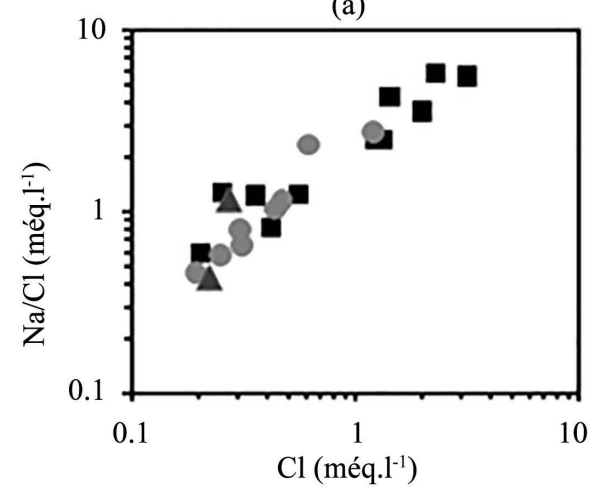

(c)

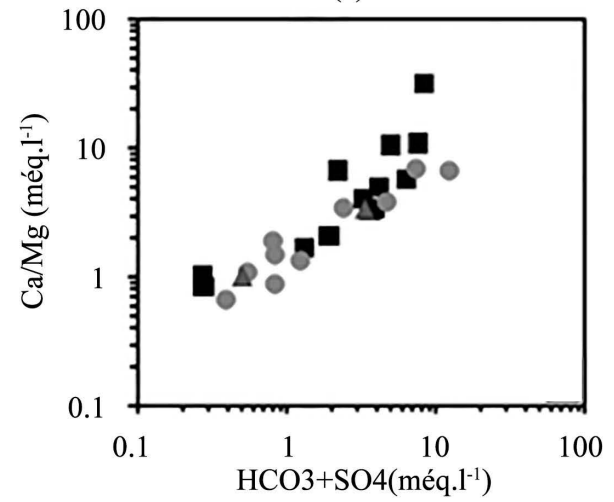

(e)

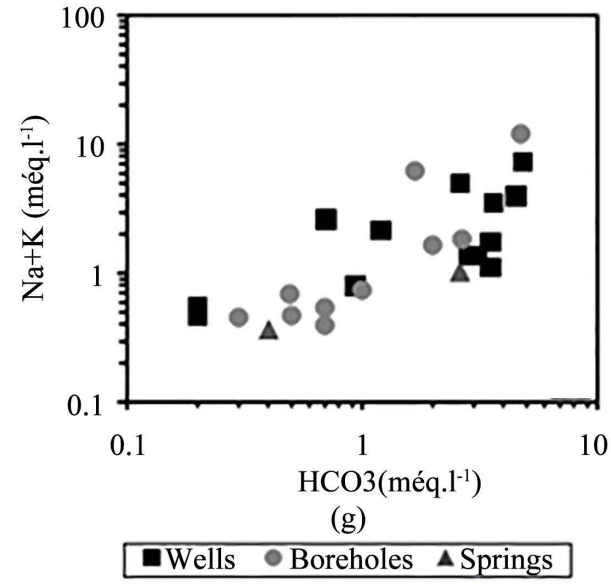

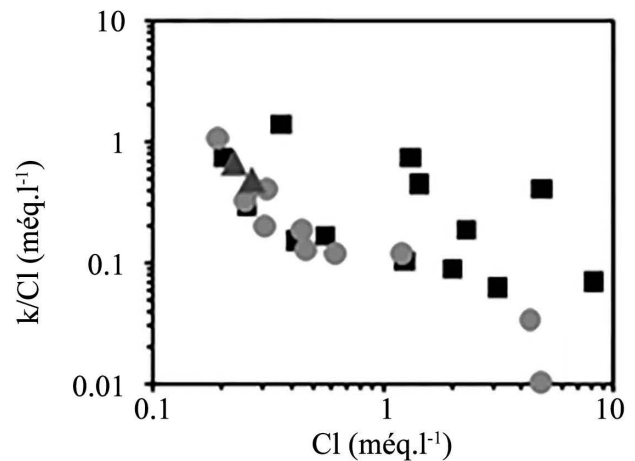

(b)

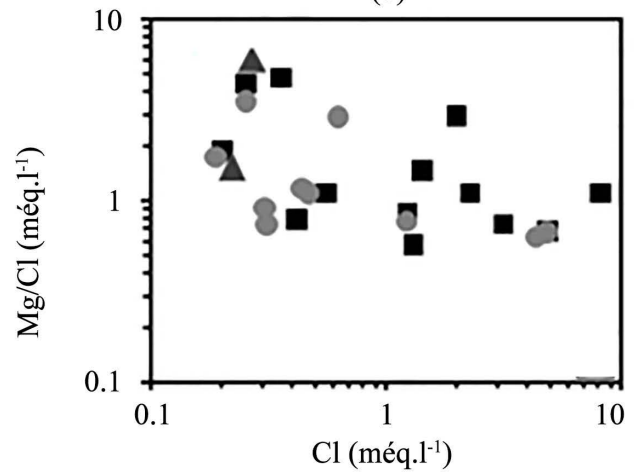

(d)

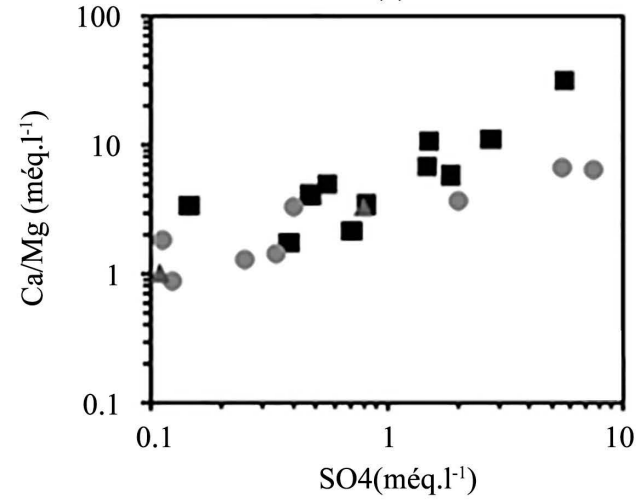

(f)

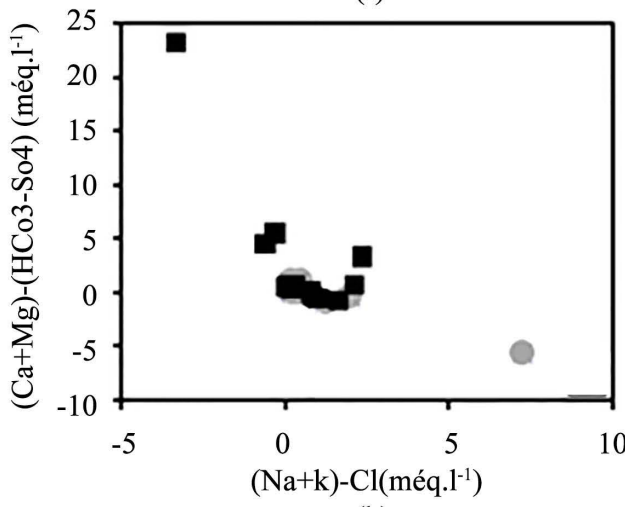

(h)

-Wells $\bullet$ Boreholes $\Delta$ Springs

Figure 5. (a) $\mathrm{Cl}$ vs. $\mathrm{Ca} / \mathrm{Cl}$; (b) $\mathrm{Cl}$ vs. $\mathrm{K} / \mathrm{Cl}$; (c) $\mathrm{Cl}$ vs. $\mathrm{Na} / \mathrm{Cl}$; (d) $\mathrm{Cl}$ vs. $\mathrm{Mg} / \mathrm{Cl}$; (e) $\left(\mathrm{HCO}_{3}+\mathrm{SO}_{4}\right)$ vs. $(\mathrm{Ca}+\mathrm{Mg})$; (f) $\mathrm{SO}_{4}$ vs. $(\mathrm{Ca}+\mathrm{Mg}) ;(\mathrm{g}) \mathrm{HCO}_{3}$ vs. $(\mathrm{Na}+\mathrm{K}) ;(\mathrm{h})((\mathrm{Na}+\mathrm{K})-\mathrm{Cl})$ vs. $((\mathrm{Ca}+\mathrm{Mg})-$ $\left.\mathrm{HCO}_{3}+\mathrm{SO}_{4}\right)$. 


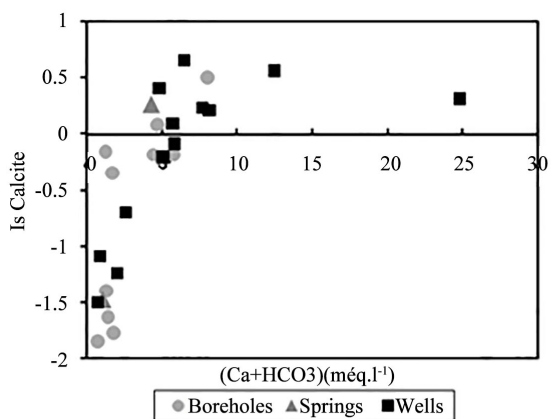

(a)

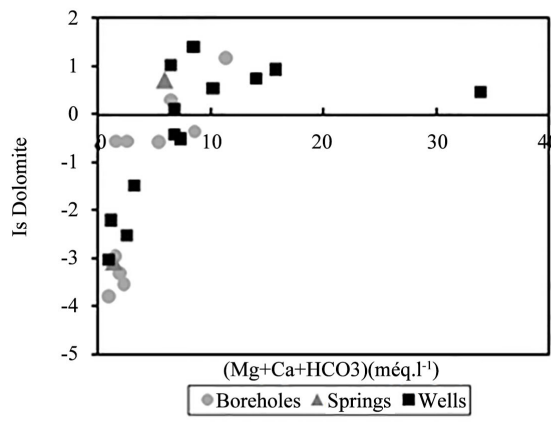

(c)

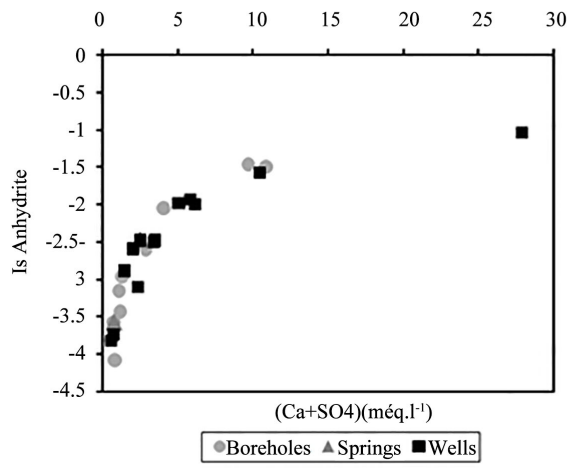

(e)

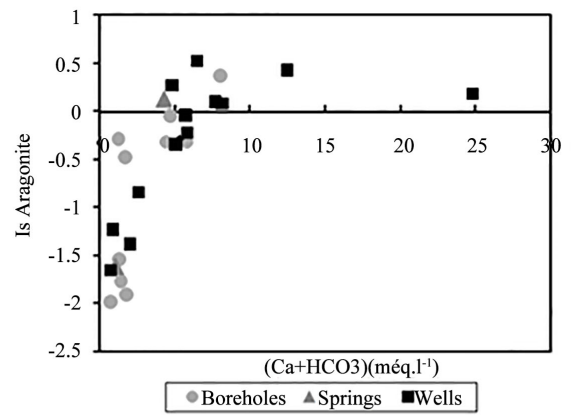

(b)

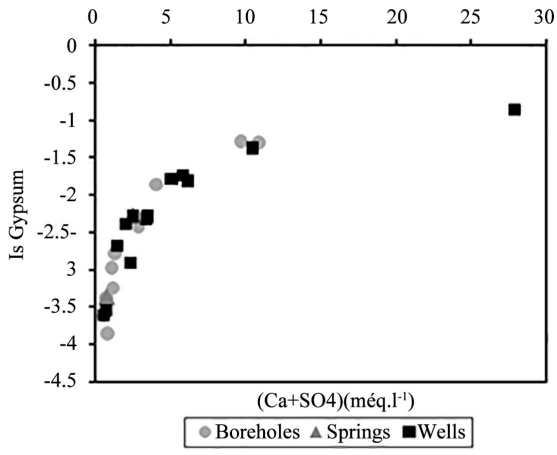

(d)

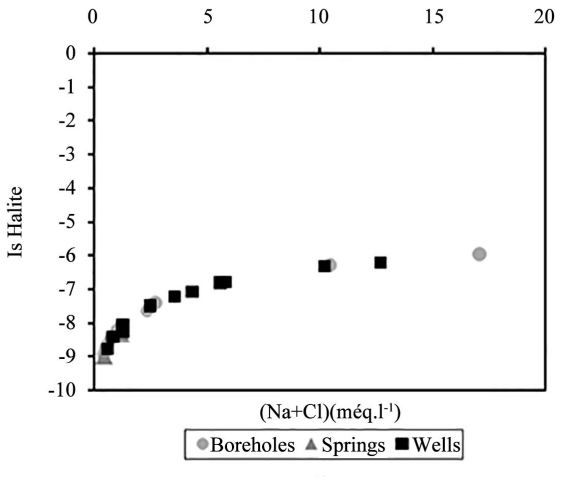

(f)

Figure 6. Correlation between the saturation indices and major elements of the Aioune sandstone water.

\subsection{Isotopic Characterization}

\subsubsection{Surface Water and Rainfall}

For rainwater, the mean value content are $-5.7 \%$ and $-36.3 \%$ V-SMOW, for $\delta$ ${ }^{18} \mathrm{O}$ and $\delta^{2} \mathrm{H}$ respectively, and are aligned on the Meteoric Water Line (MWL). For surface waters, the $\delta^{18} \mathrm{O}$ contents vary between 23.3 and 29.7\%o V-SMOW, with an average of $26.5 \%$ and for the $\delta^{2} \mathrm{H}$, values range between 99.6 to $130.2 \%$ V-SMOW, with an average of $114.9 \%$. Plotted in the conventional $\delta^{18} \mathrm{O}$ vs $\delta^{2} \mathrm{H}$, data scatter and deviate the meteoric line evidencing evaporation phenomenon and probably mixing.

\subsubsection{Groundwaters}

\section{1) Stable Isotopes and Tritium}

The $\delta^{18} \mathrm{O}$ contents vary between -5.7 and $-2.0 \% \mathrm{~V}$-SMOW, with an average 
of $-4.6 \%$ and for $\delta^{2} \mathrm{H}$, values range between -42.6 to $-20.4 \%$ o -SMOW, with an average of $-35.3 \%$. This large range probably reflects the multiple phenomena present in the system.

The $\delta^{18} \mathrm{O} / \delta^{2} \mathrm{H}$ correlation characterizes two groups, Group $\mathrm{A}$, with indirect evaporated recharge, occuring mainly at the wells and springs. Secondly, Group $B$, reflects mixing water between current and older recharge, located mainly at the boreholes (Figure 7). A significant variation of the stable isotopes of water, is recorded between 2011 and 2013, that characterize a water table with a fast response time, and also reflect the state of a superficial aquifer.

The $\delta{ }^{18} \mathrm{O}$-Depth Correlation shows a water table affected by evaporation mainly at shallow depths between $0-30 \mathrm{~m}$.

Correlation $\mathrm{Cl}-\delta^{18} \mathrm{O}$ identifies the presence of the phenomenon of dissolution, and to a less a extent evaporation phenomenon. This latter is located mainly at the shallow level.

Tritium values vary between 5.2 TU and $0.1 \mathrm{TU}$, with an average of $1.2 \mathrm{TU}$. The spatial variation of the tritium content shows the presence of local recharge, localized at the spreading zones, probably due to the topographic and favorable lithological conditions to the convergence and the water infiltration (Figure 8).

The average tritium contents of 1.5, 1 and $0.7 \mathrm{TU}$, respectively for wells, springs and boreholes, characterize the stratification of the aquifer. For some

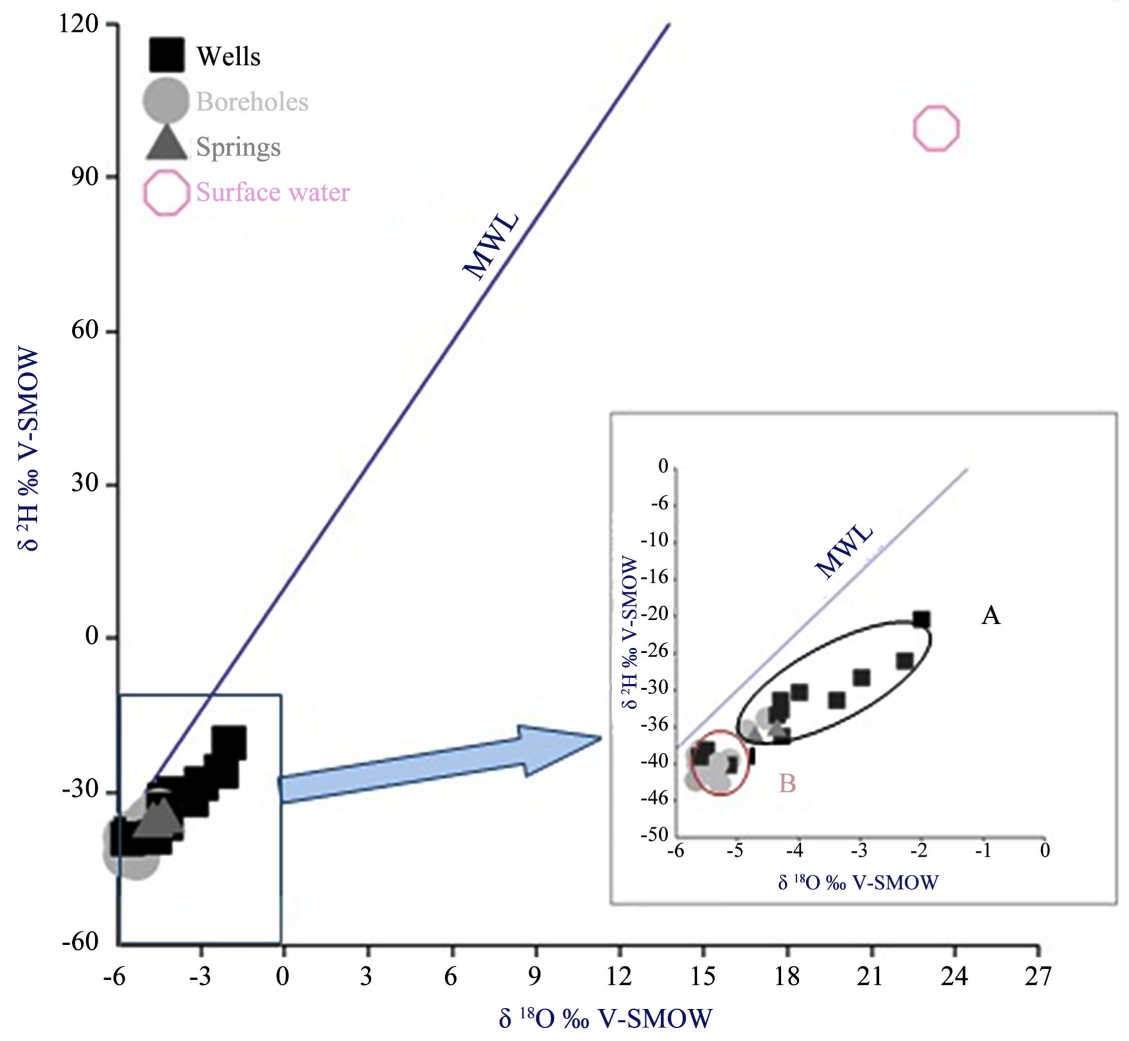

Figure 7. ${ }^{2} \mathrm{H}$ versus ${ }^{18} \mathrm{O}$ of Aioune Sandstone waters. 


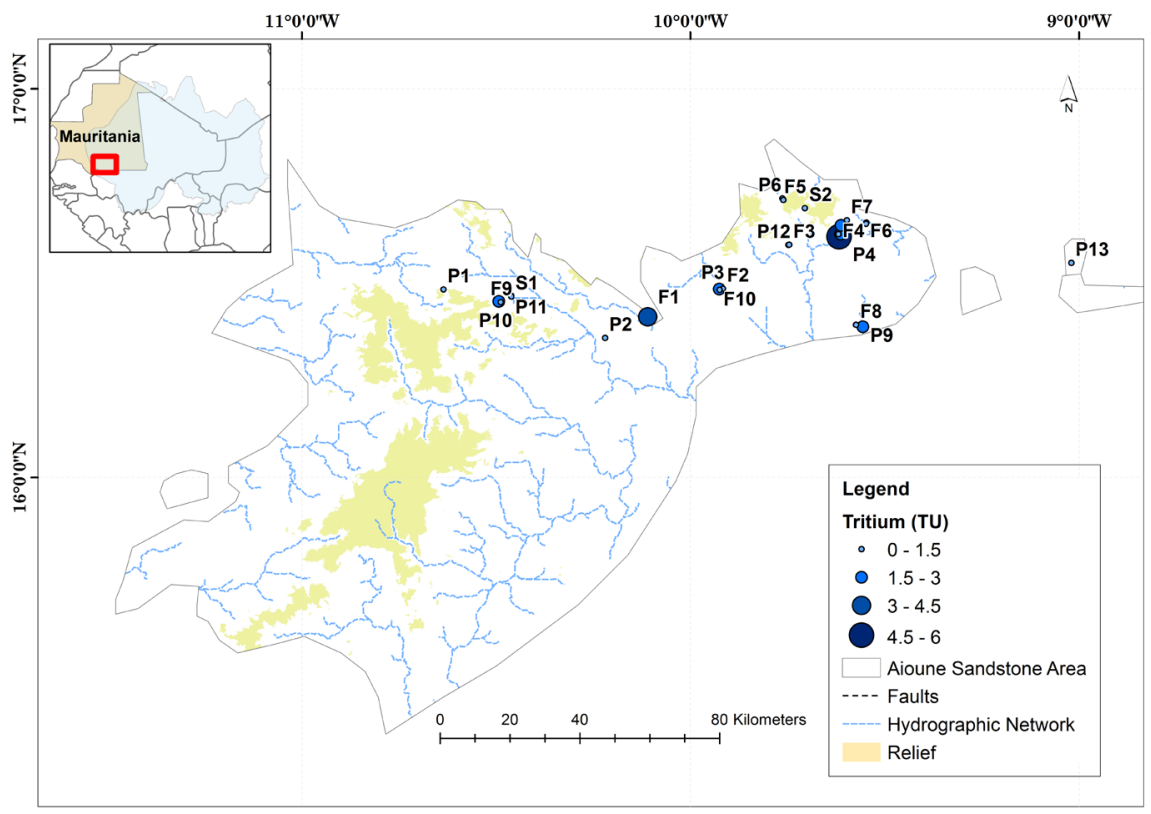

Figure 8. Tritium map of aioune aquifer (December 2011).

wells the recharge occurred after 1961 [11], while all the boreholes and springs were recharged before 1961, except the F1 borehole, which is located at Tintane City, which suffered very strong inundations in 2007, causing the evacuation of the city (Figure 9).

\section{2) Carbon Isotopes}

Correlation ${ }^{13} \mathrm{C}-{ }^{14} \mathrm{C}$ exhibits large variation in ${ }^{13} \mathrm{C}$, from -11.9 to -7.4 , indicating the presence of several carbon sources (the atmospheric reservoir and the carbonate matrix). The Aioune sandstone aquifer is characterized by a deep water enriched in $\delta^{13} \mathrm{C}$, identifying an exchange with the carbonate matrix [2]; and surface water depleted in $\delta^{13} \mathrm{C}$ (Figure 10), indicating the presence of isotopic exchange with soil $\mathrm{CO}_{2}$ or organic matter [2].

The ${ }^{13} \mathrm{C}$ equilibrium, representative of soil $\mathrm{CO}_{2}$, defines an open to intermediate system aquifer.

For the Aioune sandstone aquifer, activities in carbon 14 vary from 60 to 104 $\mathrm{pcm}$, and an average of $84 \mathrm{pcm}$, confirming the contribution of recent waters to recharge.

\section{3) Groundwater Dating}

The variation in radiocarbon contents makes it difficult to identify the initial activity $A_{0}$. Several models were used to correct this activity taking into account the different reactions. These models evolve from the simplest (model dilution), to the more complex (exchange isotopic).

In the presence of isotopic exchange between the water and the two carbon tanks, identified previously, the F and G, IAEA and Mook models are the most appropriate since they give close values; but in the presence of an open to intermediate system, the exchange phenomena with the gaseous phase and matrix, the presence of a calcareous medium [12], the IAEA model is most indicated, 

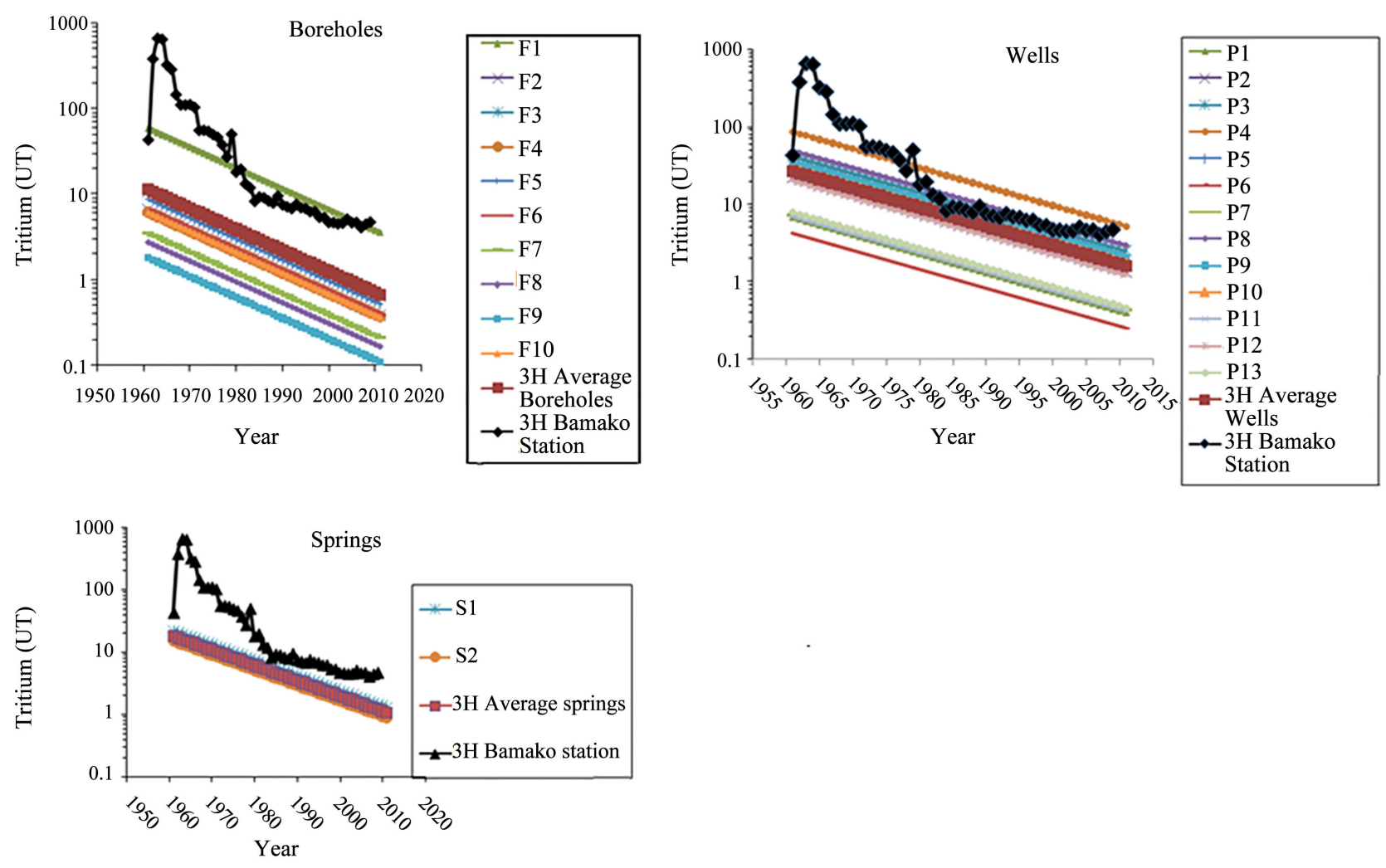

Figure 9. Datation Tritium of Aioune sandstone groundwater (2011) (pluviometric station Bamako(Mali).

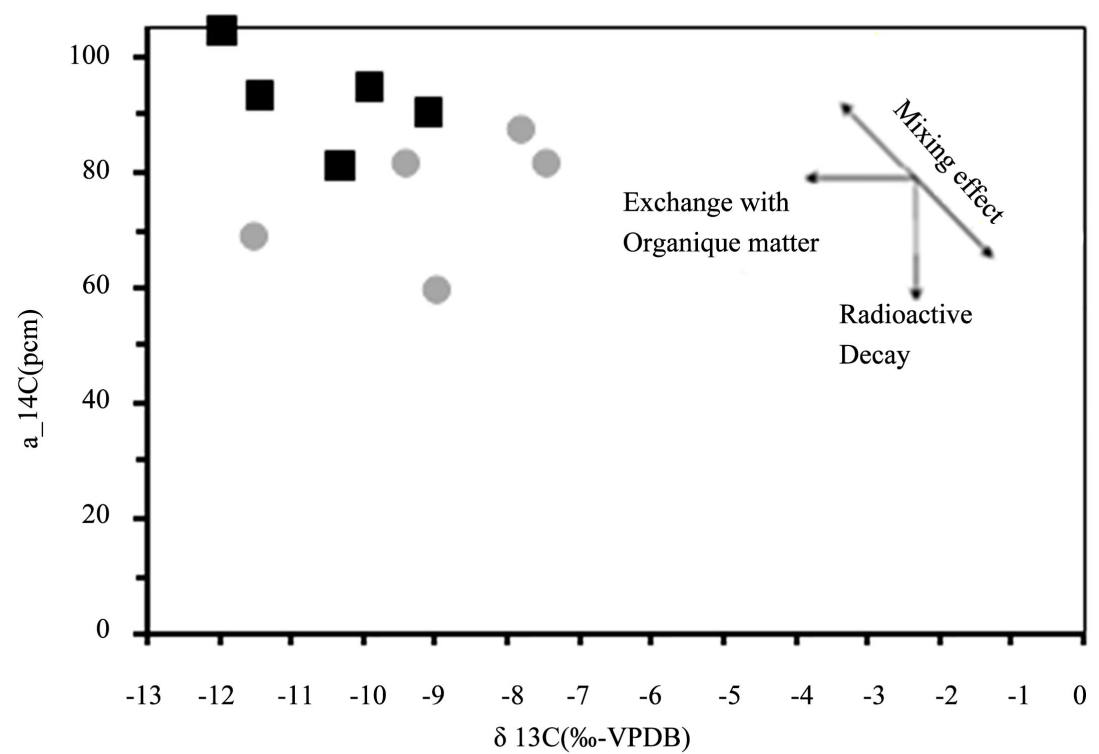

Wells Boreholes

Figure 10. Relationship between activity carbone 14-carbone 13.

and gives an age closer to the piezometric age.

The age ranges from the present to 1060 years, which is in accordance with 
the Tritium data, which characterize recent recharge (wells) to mixing water (boreholes) (Table 3).

\subsection{Recharge}

Quantification of the recharge was discussed using the chloride masse balance and the carbon 14 method.

The chloride masse balance consists of using the Allison and Hughes formula, 1978, for rainfall events greater than $5 \mathrm{~mm}$ sampled at the study area and groundwater samples from the recharge zones ( at $\mathrm{TU}>1$ ).

$$
P \times \mathrm{Cl}_{\text {rainfall }}=R \times \mathrm{Cl}_{\text {aquifer }}
$$

where $P$ : the average height of rain in $\mathrm{mm} \cdot \mathrm{year}^{-1}, R$ : the recharge in $\mathrm{mm} \cdot \mathrm{year}^{-1}$, $\mathrm{Cl}$ rain: the chloride content in precipitation in $\mathrm{mg} \cdot \mathrm{L}^{-1}$, Claq: the content of chloride in the sample in $\mathrm{mg} \cdot \mathrm{L}^{-1}$.

The ${ }^{14} \mathrm{C}$ method uses the formula adapted to free groundwater [13], which takes into account the depth of structures and the thickness collected.

$$
\mathrm{R}: H \lambda \theta \cdot \ln \left((H / H-Z)-\left(A_{0} / A\right)\right)
$$

with: $R$ : Recharge rate, $H$ : Total aquifer thickness, $Z$ : Depth of the strained area, $\theta$. Porosity, $\lambda$ : Radioactive decay constant, A: Activity measured in carbon-14, $A_{0}$ : Activity initial carbon-14.

The computed average recharges are 0.4 and $5 \mathrm{~mm} /$ year, respectively for the ${ }^{14} \mathrm{C}$ method and the chloride masse balance, which represents respective volumes of 0.4 to 5 million $\mathrm{m}^{3} /$ year.

The volume of water extracted from 494 water points (175 Wells and 319 boreholes), from the Aioune sandstone aquifer, is in the order of 6.5 million $\mathrm{m}^{3} /$ year by considering a rate of $1 \mathrm{~m}^{3} / \mathrm{hr}$ for each well and $5 \mathrm{~m}^{3} / \mathrm{hr}$ for borehole [9].

Table $3 .{ }^{14} \mathrm{C}$ Age of Aioune groundwater.

\begin{tabular}{ccccccccccc}
\hline Code & brut & Tamers & Pearson & Mook & F \& G & F \& G $\mathrm{eq}$ & AIEA & Evans & Eichinger & Olive \\
\hline P1 & 863 & actuel & actuel & actuel & actuel & actuel & actuel & actuel & actuel & actuel \\
F3 & 1661 & actuel & actuel & actuel & actuel & 83 & actuel & actuel & actuel & actuel \\
P4 & actuel & actuel & actuel & actuel & actuel & actuel & actuel & actuel & actuel & actuel \\
F5 & 1071 & actuel & actuel & actuel & actuel & 1501 & actuel & actuel & actuel & actuel \\
F6 & 1683 & actuel & actuel & actuel & actuel & actuel & actuel & actuel & actuel & actuel \\
F8 & 3035 & actuel & actuel & 1362 & actuel & 1813 & 1062 & actuel & actuel & actuel \\
P11 & 469 & actuel & actuel & actuel & actuel & actuel & actuel & actuel & actuel & actuel \\
F10 & 4258 & actuel & actuel & 793 & actuel & 2409 & 171 & actuel & actuel & actuel \\
P12 & 599 & actuel & actuel & actuel & actuel & 806 & actuel & actuel & actuel & actuel \\
P13 & 1747 & actuel & actuel & actuel & actuel & 539 & actuel & actuel & actuel & actuel \\
\hline
\end{tabular}


The comparison between the annual recharge and the annual pompung rate, evidences an imbalance in the water budget, which results in the recurrence of water shortages during summer, and makes it urgent to take appropriate measures to make sustainable and rational this water resourses.

\section{Conclusions}

This pioneering work in the Aioune sandstone one layer aquifer, located in the southern part of the Taoudenni Basin in Mauritania, is based on the interpretation of hydrodynamic (piezometry, porosity, etc.), hydrochemical (elements major) and isotopic $\left(\delta^{18} \mathrm{O}, \delta^{2} \mathrm{H}, \delta^{3} \mathrm{H}, \delta^{13} \mathrm{C}\right.$ and $\left.\delta^{14} \mathrm{C}\right)$ data to better understand the behavior of this aquifer.

Piezometrie configuration of the water table reveals effective velocity of 94 $\mathrm{m} /$ year and direction flow generally from the cliff to the plains, spreading areas. The chemical data have identified a layer whose chemical facies evolving between two poles, a calcium-magnesium bicarbonated pole (low mineralized), and a second pole chloride calcium-sodium. However, the shallow water table in part of aquifer reveals high vulnerability to pollution, especially at the shallow horizons (Douerare, Aioune). The dissolution of carbonate and evaporitic minerals is likely the main process controlling mineralization, and to a lesser extent cation exchange,

The isotopic tool allowed to identify waters classified in two groups. Group A, with indirect evaporated moderne recharge is located at the shallow level of the spraying areas; and Group B consists of mixing water, between old and modern recharge water, located deep within the water table. The sandstone Aioune aquifer is characterized by an open to intermediate system, whose water age ranges from the present day to 1060 years.

The calculated average recharge is 0.4 and $5 \mathrm{~mm}$ /year, respectively for the ${ }^{14} \mathrm{C}$ method and the chloride masse balance.

The ${ }^{14} \mathrm{C}$ method takes into account the depth of structures and the thickness collected, and the chloride masse balance consists of using the rainfall events greater than $5 \mathrm{~mm}$ and groundwater samples from the recharge area (at $\mathrm{TU}>1$ ).

Recharge compared to water pumping characterizes a water table at the limit of imbalance. In order to be able to provide a sustainable solution, it is necessary to exploit these results to arrive at a model of the water table.

\section{Acknowledgements}

The authors gratefully acknowledge the contributions of the staff members of National Center of Water Resources/Mauritania Hydraulic Ministry, for their help during field-work. We also thank the member team of Department of Geology, University Cheikh Anta Diop of Dakar, and technical staff of MAU 7003 IAEA, and also staff of the Laboratory of Radio-Analyses and Environment of the National Engineering School of Sfax (ENIS) for their constant help and assistance during laboratory analyses. Finally, we wish to thank the editors, and 
reviewers for their constructive criticism, which helped to improve the paper.

\section{References}

[1] P.N.I.S.E.R. (Projet National Integre Dans le Secteur de L'Eau en Milieu Rural) (2015) Etat des lieux du secteur de l'eau et de l'assainissement en. 177.

[2] Farid, I., Zouari, K. and Kallali, A. (2012) Origine de la salinité des eaux du Bassin de Chougafiya. Revue des Sciences de PEau, 25, 255-274. https://doi.org/10.7202/1013106ar

[3] USAID (Agence des Etats Unis pour le Développement) (1979) Mission d'étude et d'évaluation du Secteur Rural et des Ressources humaines-Zones Agroécologiques de Mauritanie. Rapport Projet RAMS, 40.

[4] Bourguet, L. (1966) Synthèse hydrogéologique et Aménagement hydraulique du Sud-est Mauritanien. Rapport 415, 88.

[5] Paloc, H. (1962) Connaissance hydrogéologique de la Mauritanie en. 75.

[6] G.G. (Géologie-Géophysique) (1988) Etude piézométrique de la nappe des grès d'Aioune. Rapport d'étude, 46.

[7] Bense, C. (1964) Les formations sédimentaires de la Mauritanie méridionale et du Mali Nord-occidental. Ph.D. mémoire, Ecole Nationale de Géologie, Vandœuvrelès-Nancy, 270.

[8] O.S.S. (Observatoire du Sahara et du Sahel) (1997) Synthèse des connaissances hydrogéologiques des bassins au Sud du Sahara. Rapport de synthèse, 85 .

[9] CNRE (Centre National des Ressources en Eau) (2013) Base de données hydraulique Nationale. SIPPE2.

[10] Abid, K. and Zouari, K. (2010) Identification and Characterisation of Hydrogeological Relays of Continental Intercalaire Aquifer of Southern Tunisia. Carbonates and Evaporites, 25, 65-75.

[11] A.I.E.A. (Agence Internationale de l'Energie Atomique) (2014) Données isotopiques GNIP des précipitations à Bamako et Vienne. http://isohis.iaea.org

[12] Fontes, J.C. (1992) Chemical and Isotopic Constraints on 14C Dating of Groundwater.

[13] Trabelsi, R. (2009) Caractérisation hydrogéologie et géochimie du système aquifère de la Djefara (Sud-Est Tunisien), modélisation et intrusion marine. Ph.D. GEA, Ecole Nationale d’Ingénieurs de Sfax, Sfax, 197. 